\title{
The Effectiveness of Draw Label Caption Strategy in Teaching Writing for EFL Students
}

\author{
Tri Setianingsih ${ }^{1)}$, I Made Permadi Utama ${ }^{2)}$ \\ ${ }^{1}$ Mandalika University of Education \\ trisetianingsih@ikipmataram.ac.id \\ ${ }^{2}$ Mandalika University of Education \\ permadi_utama@ikipmataram.ac.id
}

Received: $26^{\text {th }}$ May 2021, Revised: $30^{\text {th }}$ May 2021, Accepted: $1^{\text {st }}$ June 2021

Email Correspondence: trisetianingsih@ikipmataram.ac.id

\begin{abstract}
This research was aimed to find out whether or not the Draw Label Caption is effective toward students' writing skill. The research was experimental research and the design used was pre-experimental with pretest-posttest design. The population of the study was the second year students of SMA Hang Tuah Mataram which consisted of one class (28 students). One class was chosen by using simple sampling technique and the result of test was distributed obtain the research data. In analyzing the data was used t-test formula. The findings showed that $\mathrm{t}$-test was $(4.875)>\mathrm{t}$-table $(2.052)$ at the significant level $=$ $0,05(95 \%)$ and $\mathrm{N}=28$ students. It means that, Alternative hypothesis (Ha) is using Draw Label Caption toward students' writing skill at the second year students of SMA Hang Tuah Mataram in academic year 2019/2020 was accepted. It could be concluded that there was significant effect of Draw Label Caption toward student's writing skill at second year student of SMA Hang Tuah Mataram.
\end{abstract}

Keywords: effectiveness, label caption, strategy, EFL student.

\section{INTRODUCTION}

Writing is essential to be mastered by the learners because this is a form of result. It means writing is one of the language skills to express idea, thought, feeling and opinion in written form (Bull, 2008). Pardiyono,( 2007) said that writing is communicative act; it is a way of sharing information, thoughts, experiences, or ideas, between ourselves and others. Furthermore, according to Ghaitzh (2002), writing is a complex process that allows the writers to explore thoughts, and ideas, and make them visible concrete. Thereby, it is understandable that writing is supposed to be difficult language skill.

Writing is not a skill acquired naturally by a man just like speaking. It is culturally a specific learned behavior (Brown, 2009). In line with Brown's opinion, Harmer (2004) stated that "writing is not a skill that can be acquired by picking it up from exposure". In other words, the two experts assert 
that in order to acquire writing skill normally needs some forms of instruction from someone else. Writing emerges in society because spoken language cannot fulfill communicative needs which resulted from cultural change.

Sugianto (2008) stated that "one of successful writing in using grammatical system is to convey one's intended meaning. Barnet \& Marcia ( 1990) said that writing is considered as the most difficult skill since it involves several components including contents, organization, vocabulary, grammar structure, and mechanic; Cohen (1994) also stated that "assessing of writing task such as content, organization, grammatical structure, vocabulary, and mechanic (spelling, punctuation, and capitalization)". Assessing writing means how teacher give score of writing to students. In this research, the researcher assessed the students' writing using Cohen's theory.

Writing skill becomes important because of the progress of knowledge, information and technology. Moreover, teaching writing is not easy. Besides, teachers must be creative to determine appropriate technique in teaching writing activity especially for many genres of the text such as narrative, descriptive, recount, procedure, news item, and report text. All of the texts have important position to be used as object of learning in every day. Descriptive text is one of texts that should be taught at school. A descriptive text is a genre of text that provides illustration about place, thing, and person in detail. In line with the problem above, Draw Label Caption strategy is offered as an alternative in teaching descriptive text.

According to Bull (2008) that Drawing is "art or skill of making pictures, plants, etc." Label is "a small piece of paper or put a label on something in a particular way. Caption is a short piece of text under a picture in a book, magazine or newspaper which describes the picture or explains what the people in it are doing or saying. That is a strategy which is used to make the students easier in writing the text in English especially descriptive text, so that Draw Label Caption strategy can help the students to do it. In this case, there are three stages of Draw Label Caption. Firstly, draw stage in which the students draw anything that they want. Secondly, label stage in which the students give name in every drawing in detail. The last is caption stage in which the students change names of the drawing to become a sentence. Finally, the students are demanded to cluster sentences to be a paragraph.

An observation is conducted by the present researcher at SMA Hang Tuah Mataram. When students follow English learning process especially writing, the researcher find that students in learning have a difficulty to write even the simple sentence or words, the students often do the simple mistake when the teacher asks to write simple short sentence or words; such as students have no an idea what to write and how to write in simple way. It problems occur because of the students are not accustomed and lack of interest so that is why the students hard to understand teacher instruction when they are in learning process. 
Some problems above are caused by two factors: the factor from a teachers and factor from the students themselves. Factor shortage of teachers in the learning process among others, lack of teachers' skills in teaching using media and technology education so that the learning process is not effective and efficient, delivery of a material is traditionally supposed to be changed by using the method or the new strategy so that students are interested and not bored during the learning process and the latter approach is the lack of teachers who have a good care to the students in learning so that teachers do not know the characteristics of their students.

The shortage of students comes from factor of internal and external. Internal factors such as factor physiological effect on the brain's ability of students and factors psychological effect on the feelings of the students, while factors external can come from social factors that influenced by the environment of parents and the community which have a major impact to the students that can not to be denied during the process of learning progress.

This occurs because of the way teachers in teaching do not interest for students, teachers have to be more creative and innovative in teaching by implementing a new method or strategy that can make students happy and suggested when learning. It can be concluded that the role of teachers and students in the process is important in order to achieve quality education as expected.

When the students learn English, they have to reduce a stress. The teacher may not give many difficult exercises that make them stress. The teacher should to make the class relax and not boring. In order to make the students interest when they learn English, there is some method to teach especially in Teaching Writing. As a teaching media, Draw Label Caption is needed and very essential to clarify information, especially in teaching vocabulary. Draw Label Caption is also used to help teacher to improve the effectiveness of teaching learning activity as well.

Based on the phenomenon above, the present researcher intends to investigate "the effectiveness of Draw-Label-Caption strategy in teaching writing of descriptive text to the students of SMA Hang Tuah Mataram.

\section{RESEARCH METHOD}

\section{Research Design}

Sugiyono (2011) divides experimental research design into four, namely pre-experimental, true experimental, factorial experimental and quasi experimental. In this research, the present researcher chose pre-experimental design by using one group experiment which is called one-group pretest-posttest design. In this case, the present researcher investigates the difference both in pre-test and post-test result before and after giving treatment by using Draw Label Caption strategy.

This research belongs to experimental. The present researcher chose pre-experimental design by using one group experiment which is called one-group pretest-posttest design. The population of 
this research is all students of the second grade of SMA Hang Tuah Mataram which consist of 2 classes (2A and 2B). In class $2 \mathrm{~A}$ consist of 28 students and in class $2 \mathrm{~B}$ consist of 20 students, it means that total of the population there are 48 students.

In this research, the present researchers take one class (Class 2A) which consists of 28 students at the second grade students of SMA Hang Tuah Mataram as the sample of this research. The instrument of this research uses two tests (pre-test post-test), the test is used to find out whether or not Draw Label Caption is effective in teaching writing of descriptive text. The test is given in the beginning and in the end of the treatments. The test is in form of writing test.

\section{Techniques of Data Analysis}

1. Descriptive Analysis

a. Mean

The formula is:

$$
\bar{X}=\frac{\sum f i x i}{N}
$$

\section{Where:}

$\overline{\mathrm{X}} \quad=$ the symbol of mean

$\Sigma \quad=$ the sum of deviation

$x i \quad=$ for any score in the set

fi $\quad=$ frequency

$\mathrm{N}=$ the total number of sample

(Arikunto, 2013)

b. Median

The formula is:

$$
M_{d}=L+i\left(\frac{\frac{n}{2}-c f b}{f w}\right)
$$

\section{Where:}

$M_{d} \quad=$ median score

$L \quad=$ lower limit of the median class

$i \quad=$ interval

$\mathrm{fw} \quad=$ total of all the frequencies before the median class

$c f b=$ the cumulative frequency in all interval below the interval containing the median

$n \quad=$ total of all the frequencies

(Arikunto, 2013)

c. Mode 
The formula is:

$$
M o=L+i\left(\frac{f i}{f i+f 2}\right)
$$

Where:

Mo $\quad$ = Mode Score

$L \quad=$ The lower limit of the interval within which the mode lies

$i$ =Interval (class width)

$f_{1}=$ The frequency of the interval containing mode reduce that previous interval.

$f_{2} \quad=$ The frequency of the interval containing mode reduced by that of following interval

(Arikunto, 2013)

d. Standard Deviation

The formula is:

$S=\sqrt{\frac{\sum f i X i^{2-\frac{\left(\sum f i X i\right)}{n}}}{n-1}}$

\section{Where:}

$\mathrm{S} \quad=$ Standard Deviation

$\Sigma \quad=$ The sum of summation

fi $\quad=$ Frequency

$X i \quad=$ Each score in the set

$n \quad=$ The number of sample

(Arikunto, 2013)

2. Inferential Analysis

a. The formula for $\mathrm{t}$-test:

$$
\mathrm{t}=\frac{\bar{D}}{\sqrt{\frac{\sum D^{2}-\frac{\left(\sum D\right)^{2}}{N(N-1)}}{N(N)}}}
$$

\section{Where:}

t $\quad$ The significance of experimental group to control group

$\bar{D} \quad$ : Mean score of deviation of pre-test and post-test

$\mathrm{N} \quad$ : The unit of sample 


\section{$\sum D^{2} \quad$ : The sum of deviation quadrat \\ $\sum D \quad$ : The sum of deviation}

\section{FINDINGS AND DISCUSSION}

\subsection{Research Finding}

Table 1. Students' score of Pre-test and Post-test

\begin{tabular}{|c|c|c|c|c|c|}
\hline No. & Students & Pre-test & Post-test & Deviation & $\begin{array}{c}\text { Deviation } \\
\text { Square }\end{array}$ \\
\hline 1 & AA & 46 & 60 & 14 & 196 \\
\hline 2 & $\mathrm{AB}$ & 36 & 62 & 26 & 676 \\
\hline 3 & $\mathrm{AC}$ & 40 & 58 & 18 & 324 \\
\hline 4 & $\mathrm{AD}$ & 30 & 44 & 14 & 196 \\
\hline 5 & $\mathrm{D}$ & 50 & 58 & 8 & 64 \\
\hline 6 & DA & 56 & 68 & 12 & 144 \\
\hline 7 & $\mathrm{EE}$ & 42 & 60 & 18 & 324 \\
\hline 8 & EB & 34 & 50 & 16 & 256 \\
\hline 9 & FA & 26 & 32 & 6 & 36 \\
\hline 10 & HB & 28 & 60 & 32 & 1024 \\
\hline 11 & $\mathrm{IH}$ & 46 & 70 & 24 & 576 \\
\hline 12 & IK & 58 & 78 & 20 & 400 \\
\hline 13 & $\mathrm{KH}$ & 20 & 36 & 16 & 256 \\
\hline 14 & LAI & 28 & 42 & 14 & 196 \\
\hline 15 & LBA & 34 & 56 & 22 & 484 \\
\hline 16 & MMA & 40 & 64 & 24 & 576 \\
\hline 17 & $\mathrm{~N}$ & 48 & 62 & 14 & 196 \\
\hline 18 & RA & 20 & 38 & 18 & 324 \\
\hline 19 & RB & 34 & 64 & 30 & 900 \\
\hline 20 & $\mathrm{RC}$ & 30 & 48 & 18 & 324 \\
\hline 21 & $\mathrm{RB}$ & 48 & 54 & 6 & 36 \\
\hline 22 & SA & 28 & 50 & 22 & 484 \\
\hline 23 & SB & 26 & 58 & 32 & 1024 \\
\hline 24 & $\mathrm{SC}$ & 30 & 62 & 32 & 1024 \\
\hline 25 & WA & 58 & 80 & 22 & 484 \\
\hline 26 & WB & 42 & 60 & 18 & 324 \\
\hline 27 & WD & 34 & 58 & 24 & 576 \\
\hline 28 & WE & 40 & 64 & 24 & 576 \\
\hline \multicolumn{2}{|l|}{$\mathrm{N}=28$} & $\Sigma 1052$ & $\Sigma 1596$ & $\Sigma 544$ & $\Sigma 12000$ \\
\hline \multicolumn{2}{|c|}{ MEAN SCORE } & 37 & 57 & & \\
\hline
\end{tabular}

\section{1.1. Descriptive Analysis}

Dealing with the table score of the students score above it was obtained the total score of Pretest was $\sum 1052$, Post-test was $\sum 1596$, Deviation was $\sum 544$, and Deviation Square was $\sum 12000$. After the total score both of the tests obtained,the work continued to the computation of the mean score of the tests. 


\section{Data Interpretation of Pre-test}

1) Mean score of Pre-test

$$
\begin{aligned}
M X_{1} & =\frac{\sum X_{1}}{N} \\
& =\frac{1052}{28} \\
& =37.5
\end{aligned}
$$

1. The highest score was 58

2. The lowest score was 20

3. Range (r) is $58-20=38$

4. The number of class is $1+(3.3) \log 28=1+(3.3)(14471)=6$ Use 5 or 6 , in this case 6 was used.

5. Class width (interval) $=38 / 6=6.33$. Use 6 or 7 , in this case 7 was used.

2) Mode Score of Pre-test

$$
\begin{aligned}
& \text { Mo }=33.5+7\left(\frac{2}{2+6}\right) \\
& \text { Mo }=35.25 .
\end{aligned}
$$

Based on the data above, it can be seen that the mode score of Pre-test was 35.25.

3) Median score of Pre-test

$$
\begin{aligned}
\mathrm{Me} & =\mathrm{L}+\mathrm{i}\left(\frac{\frac{n}{2}-c f b}{f w}\right) \\
\mathrm{Me} & =33.5+7\left(\frac{\frac{28}{2}-10}{8}\right) \\
& =37 .
\end{aligned}
$$

Based on the data above it can be seen that the median score of Pre-test of the students was 37

\section{Data Interpretation of Post-test}

1) Mean Score of Post-test

$$
\begin{aligned}
M X_{2} & =\frac{\sum X_{2}}{N} \\
& =\frac{1596}{28} \\
& =57
\end{aligned}
$$

1. The highest score is 80

2. The lowest score is 32

3. Range (r) is $80-32=48$

4. The number of class is $1+(3.3) \log 28$ 


$$
\begin{aligned}
& =1+(3.3)(1,4471) \\
& =5.7756 .
\end{aligned}
$$

Use 5 or 6 , in this case 6 was used.

5. Class width (interval) $=48 / 6=8$ was used

2) Mode score of Post-test

$$
\begin{aligned}
\text { Mo } & =55.5+8\left(\frac{8}{8+7}\right) \\
& =57.9
\end{aligned}
$$

3) Median score of Post-test

$$
\begin{aligned}
\text { Me } & =55.5+8\left(\frac{\frac{28}{2}-9}{8}\right) \\
& =60.46
\end{aligned}
$$

\section{Computation and Interpretation of Standard Deviation Score}

$$
\begin{aligned}
& \mathrm{SD}_{\mathrm{D}}=\sqrt{\frac{\sum \mathrm{D}^{2}}{\mathrm{~N}}-\left(\frac{\sum \mathrm{D}}{\mathrm{N}}\right)^{2}} \\
& =\sqrt{\frac{12000}{28}-\left(\frac{544}{28}\right)} 2 \\
& =\sqrt{428.57-(19.42)} \\
& =\sqrt{428.57-(377.13)} \\
& =\sqrt{51.44} \\
& =7.17
\end{aligned}
$$

The result was sum of deviation score $(\Sigma \mathrm{D})$ was 544 and sum of quadrate deviation score $\left(\Sigma \mathrm{D}^{2}\right)$ was 12000 . 


\section{Inferential Analysis}

The researcher intended to analyze the data by using t-test formula as last step. The formula it as follows:

$$
\begin{aligned}
& t=\frac{\bar{D}}{\sqrt{\frac{\sum D^{2}-\frac{(\Sigma D)^{2}}{N(N-1)}}{N(N-1)}}} \\
&=\frac{544}{\sqrt{\frac{12000-\frac{(544)^{2}}{28(28-1)}}{2}}} \\
&=\frac{544}{\sqrt{\frac{12000-\frac{295936}{28(28-1)}}{2}}} \\
&=\frac{544}{\sqrt{\frac{12000-10.569}{756}}} \\
&=\frac{544}{\sqrt{\frac{12010.569}{756}}} \\
&=\frac{544}{\sqrt{15.886}} \\
&=\frac{544}{3.985} \\
&=4.875 \\
& \mathbf{t}_{\mathrm{o}}=\mathbf{( 4 . 8 7 5 )}>\mathrm{t}_{\mathrm{t}}=\mathbf{2 7}(\mathbf{2 . 0 5 2})
\end{aligned}
$$

\subsection{Discussion}

In this term, the result of the value, it is needed consult t-table by using $\mathrm{N}-1$ as the degree freedom (df). The $\mathrm{df}$ is $\mathrm{N}-1=28-1=27$, having known the value of $\mathbf{d f}$, the researcher needed to cheeked up the t-table of $\mathbf{d f} 27$.And the researcher found that the value was $4.875>2.052$ for confidence level of 0.05 (95\%). Therefore, the alternative hypothesis $\left(\mathrm{H}_{\mathrm{a}}\right)$, which state: "Draw Label Caption" is still effective for teaching writing for EFL students of SMA Hang Tuah Mataram in academic year 2019/2020.

\section{Conclusion}

The statistical analysis of the data obtained showed that the figures of student's mean score of pre-test was 37.57 and 57 for pos-test. The student's mean score of post-test was higher than pre-test. This was taken based on the result of the t-test, it was found that t-test was 4.875 and t-table at 
significance level of $0.05(95 \%)$ was 2.052. Thus, t-test was higher than t-table. So, it indicated that

"Draw Label Caption" as technique can be used in teaching writing skill. It showed that Alternative Hypothesis $\left(\mathrm{H}_{\mathrm{a}}\right)$ was accepted and Null $\left(\mathrm{H}_{\mathrm{o}}\right)$ Hypothesis was rejected.

\section{REFERENCES}

Arikunto, S. (2013). Prosedur Penelitian: Suatu Pendekatan Praktek. P.T. Rineka Cipta.

Barnet, S., \& Marcia, S. (1990). Practical Guide to Write with Additional Reading. Harper Collins Publisher.

Brown, D. H. (2009). Language Assessment: Principles and Classroom Practices. State University.

Bull, V. (2008). Definition of Writing.Oxford Learners' Pocket Dictionary (Fourth edition). Oxford University Press.

Cohen, L. (1994). Research Method in Education (Sixth Edition). Routledge.

Ghaitzh, G. (2002). The nature of writing process: Approach, Model and Process Writing Activities. http://ghaitzh.ksx.org

Harmer, J. (2004). The Practice of English Language Teaching (4th ed.). Pearson Education.

Pardiyono, D. (2007). Metoda Mengajar Writing Berbasis Genre Secara Effektif.

Sugianto. (2008). Metode Penelitian Qualitative dan Quantitative. Alfabeta.

Sugiyono. (2011). Metode Penelitian Pendidikan. Alfabeta. 